\title{
Effectiveness of comprehensive tobacco control programmes in reducing teenage smoking in the USA
}

\author{
Melanie Wakefield, Frank Chaloupka
}

\begin{abstract}
Objective-To describe the extent to which comprehensive statewide tobacco control programmes in the USA have made progress toward reducing teenage smoking.

Data sources-Literature search of
\end{abstract} Medline for reviews of effectiveness of programme and policy elements, plus journal articles and personal request for copies of publicly released reports and working papers from evaluation staff in each of the state programmes of California, Massachusetts, Arizona, Oregon, and Florida.

Study selection-All studies, reports, and commentaries that provided information on aspects of programme implementation and evaluation.

Data synthesis-Statewide comprehensive programmes show high levels of advertising recall and generally positive improvement in smoking related beliefs and attitudes among teenagers. More fully funded programmes lead to increased mass media campaign advertising and community initiatives; a greater capacity to implement school based smoking prevention programmes; and an increase in the passage of local ordinances that create smoke free indoor environments and reduce cigarette sales to youth. The combination of programme activity and increased tobacco tax reduce cigarette consumption more than expected as a result of price increases alone, and these effects seem to apply to adolescents as well as adults. Programmes are associated with a decline in adult smoking prevalence, with these effects observed to date in California, Massachusetts, and Oregon. Arizona and Florida have yet to examine change in adult prevalence associated with programme exposure. California and Massachusetts have demonstrated relative beneficial effects in teenage smoking prevalence, and Florida has reported promising indications of reduced prevalence. Arizona has yet to report follow up data, and Oregon has found no change in teenage smoking, but has only two years of follow up available. One of the most critical factors in programme success is the extent of programme funding, and consequent level of programme implementation, and the degree to which this is undermined by the tobacco industry and other competitors for funding.

Conclusions-Despite the different strengths and combinations of programme messages and strategies used in these comprehensive programmes, there is evidence that they lead to change in factors that influence teenage smoking, and to reductions in teenage smoking.

(Tobacco Control 2000;9:177-186)

Keywords: comprehensive tobacco control programmes; teenage smoking

Statewide comprehensive tobacco control programmes aim to involve a range of coordinated and coexisting tobacco control strategies, so that they reinforce and complement each other in a synergistic fashion. A distinguishing feature of comprehensive programmes is their focus on changing smoking behaviour at the population level through strategies which alter the social environment in which smoking uptake and cessation occurs. ${ }^{1-3}$ Often, these programmes have been funded by an increase in the excise tax on cigarettes, with part being allocated to fund a tobacco control programme. Such programmes were first initiated in the USA in California (from 1989) and then in Massachusetts (from 1993), Arizona (from 1994), and Oregon (from 1996). In addition, Florida began a comprehensive programme from 1997, which was funded by a percentage of money from that state's settlement with the tobacco industry, rather than a tax increase. These comprehensive programmes involve some mix of the following elements: public education through electronic, outdoor, and print media campaigns; development and enforcement of policies to prevent youth access to tobacco, restrict tobacco advertising, and/or create smoke-free environments; community initiatives, involving grants to local organisations to facilitate worksite programmes, training and assistance for health professionals to improve cessation services, and policy development; school based programmes focusing on curriculum development, school policy, and prevention; direct cessation services for smokers, such as telephone helplines and other quit smoking materials; and research and evaluation.

The aim of this paper is to review and synthesise the publicly available findings from the five statewide comprehensive tobacco control programmes in the USA, and to draw conclusions about the extent to which they have reduced teenage smoking, or are making progress along a pathway likely to lead to 
reductions in teenage smoking. This information is important to assist decision making by those who would fund such programmes, such as other US states considering how to allocate funding from the multi-state settlement agreement, and for other countries who may be looking to the experience of these states as a model for establishing their own comprehensive tobacco control programmes.

\section{The research context underpinning comprehensive tobacco control programmes}

Controlled research studies can identify tobacco control strategies with the potential to reduce teenage tobacco use when applied more widely. However, evaluation of the extent to which they achieve these aims when implemented in practice as part of comprehensive statewide tobacco control programmes is rather more difficult to determine. In any assessment of the effectiveness of tobacco control programmes in reducing teenage tobacco use, it is vital to understand why this is so. There are five main factors that can mislead: (1) changing population smoking prevalence is likely to be a relatively slow process, even in response to comprehensive programmes; (2) smoking prevalence is usually only measured yearly or less frequently and sampling variation and different survey methodologies make these measures insensitive tools for assessing early change; (3) changes in smoking behaviour and prevalence can reflect societal influences unrelated to new tobacco control programmes; (4) actual implementation of programme strategies may differ substantially from intended implementation and the extent of disparity may vary over time and between programmes; and (5) tobacco industry activities may undermine tobacco control programmes and falsely suggest the programmes are ineffective when, in fact, they could be very effective in the absence of industry efforts. For all these reasons, assessment of progress requires much more than a cursory comparison of teenage smoking prevalence in states with and without such programmes.

We argue for taking a larger view that takes account of the amount of programme expenditure and extent of implementation, and evaluates markers of progress in factors known to mediate teenage tobacco smoking, ${ }^{4}{ }^{5}$ as well as change in tobacco smoking itself. From the outset, it is important to have a clear assessment of the evidence for reducing adolescent smoking for the elements that comprise a comprehensive tobacco control programme. This provides a rationale as to why such programmes might be expected to reduce adolescent smoking when implemented on a statewide basis. Much of the evidence for effectiveness of these elements has been gained from research applied to relatively small, discrete populations in controlled experimental studies. Unlike examination of the effects of school based prevention programmes, community wide tobacco policy research has only recently been possible to undertake, since policies are less amenable to experimental simulation and need to be actually implemented in whole populations before effects can be judged. Nonetheless, in the past decade, great strides have been made in our understanding of the types of policies that influence smoking. However, the precise mechanisms by which such policies affect teenage smoking are often unclear. For example, while some policies seem to exert more immediate influence on overall measures of tobacco consumption and adult smoking prevalence in the short term, they may affect teenage use in the longer term through distinctly changing societal norms about smoking. However, these indirect effects are no less important and may be more enduring.

Reviews of the effectiveness of school based smoking prevention programmes suggest that programmes using the social influences model are most effective for reducing tobacco use. ${ }^{6-8}$ Effects dissipate over time, ${ }^{9-11}$ but can be sustained with mass media interventions or community-based tobacco control strategies. ${ }^{812-14}$ Mass media campaigns alone can reduce population smoking behaviour ${ }^{15} 16$ and are associated with attitudes more disposed to quitting or not starting among teenagers. ${ }^{17-19}$ However, as already noted, the most reliable effects are observed once mass media campaigns are combined with social influences school based prevention programmes. ${ }^{12}$

Recent controlled intervention studies of reduced youth access to tobacco, ${ }^{20}{ }^{21}$ a study relating serial cross sectional surveys of US school children with youth access laws, ${ }^{22}$ and a comprehensive review ${ }^{23}$ have suggested that a very high level of retailer compliance, coupled with community involvement, may be necessary before youth smoking rates are affected. In terms of restrictions on smoking, it is known that schools with comprehensive policies that ban smoking on school premises have significantly lower rates of student smoking. ${ }^{24}$ The extensiveness of restrictions on smoking in public places has been found to be associated with reduced smoking among US schoolchildren ${ }^{25}$ and young adults. ${ }^{26} \mathrm{~A}$ recent comprehensive review indicates that complete, but not partial, bans on advertising do influence aggregate cigarette consumption. ${ }^{27}$ Evidence generally supports the argument that cigarette advertising and promotion directly and indirectly increases cigarette demand and brand share, particularly among youth. ${ }^{828-30}$ Level of interest in tobacco advertising and promotions is related to uptake of smoking. ${ }^{30-33}$ Finally, numerous studies conclude that higher cigarette prices lead to reductions in overall smoking, ${ }^{27}$ and many studies have confirmed that teens and young adults are relatively more price responsive than adults. ${ }^{25} 2634-37$

In summary, there is good reason to expect that school based prevention programmes using a social influences approach, mass media campaigns, restrictions on smoking in schools and public places, strongly enforced limits on youth access, a complete ban on tobacco advertising, and real price increases in 
cigarettes, will lead to reductions in teenage smoking. In providing a brief overview of this evidence, it is plain that individual tobacco control strategies are not independent, but can reinforce each other in the pursuit of reducing teenage smoking. Therefore, a community wide sustained effort using multiple channels of influence has the most likelihood of producing real and durable changes in adolescent smoking.

\section{Approach to the review}

In evaluating comprehensive programmes, consideration needs to be given to a range of indicators, which assess both the amount and type of tobacco control "input" - namely, what was actually implemented as part of the programmes - as well as the amount and type of promotional and other strategies used to encourage and promote smoking on the part of tobacco companies. ${ }^{38}$ This helps to establish whether one might reasonably expect change at the population level for the actually implemented level of programme input and policy change, as well as an explanation for any variation over time in markers of progress towards reduced teenage tobacco use.

If we accept the evidence that particular policies and programmes have been shown to influence teenage tobacco use, then measures of actual policy enactment and implementation, as well as measures of programme delivery and receipt, should be viewed as markers of progress towards the longer term aim of achieving reduction in adolescent smoking. In reviewing evidence for the effectiveness of comprehensive tobacco control programmes in reducing teenage tobacco use, we focus upon: measures of programme implementation and strength, such as overall programme funding and allocation to different strategies, and tobacco industry efforts to counter the aims of these programmes; intermediate markers of progress (including awareness of campaign messages by youth, beliefs about smoking and passive smoking, and support for tobacco control strategies); changes in factors that denormalise smoking (such as decreasing youth access to tobacco, creating more restrictions on smoking, restricting tobacco advertising); consumption; adult smoking; adolescent intentions and uptake continuum measures; and finally teen smoking prevalence.

\section{Study selection}

Medline was searched for all published studies of aspects of programme implementation and evaluation pertaining to each of the state programmes. In addition, contact was made with each of the evaluation coordinators in each state and a request made for publicly available evaluation reports and commentaries about their programmes up to October 1999.

\section{Data synthesis}

CALIFORNIA (1989-PRESENT)

The California Tobacco Control Program (CTCP), funded by Proposition 99, was the first comprehensive statewide tobacco control programme in the USA. In the main, the

Table 1 Overview of elements of five comprehensive statewide tobacco control programmes in the USA to 1998-99.

\begin{tabular}{|c|c|c|c|c|c|}
\hline & California & Massachusetts & Arizona & Oregon & Florida \\
\hline \multirow[t]{2}{*}{$\begin{array}{l}\text { Programme funding } \\
\text { source and cigarette } \\
\text { price increases }\end{array}$} & $\begin{array}{l}\text { 1989: tax increase by } 25 \\
\text { cents to } 35 \text { cents/pack, } \\
\text { earmarked } 20 \% \text { of } \\
\text { revenue for tobacco } \\
\text { control }^{34}\end{array}$ & $\begin{array}{l}\text { 1993: tax increase by } 25 \\
\text { cents to } 51 \text { cents per } \\
\text { pack }^{53} 1996 \text { : tax increase } \\
\text { by } 25 \text { cents to } 76 \\
\text { cents/pack, and increases } \\
\text { for loose tobacco and } \\
\text { cigars }^{53}\end{array}$ & $\begin{array}{l}\text { 1994: tax increase by } 40 \\
\text { cents to } 58 \text { cents/pack } \\
\text { and increased tax on } \\
\text { other tobacco products, } \\
\text { earmarked } 23 \% \text { of } \\
\text { revenue for tobacco } \\
\text { control }^{63}\end{array}$ & $\begin{array}{l}\text { 1996: tax increase by } 30 \\
\text { cents to } 68 \text { cents per } \\
\text { pack, earmarked } 10 \% \text { of } \\
\text { increase for tobacco } \\
\text { control }^{69}\end{array}$ & $\begin{array}{l}\text { 1997: Florida tobacco } \\
\text { settlement funding, but no } \\
\text { tax increase }\end{array}$ \\
\hline & \multicolumn{5}{|c|}{$\begin{array}{l}\text { November 1998: national } 45 \text { cent price increase due to multi-state settlement agreement, followed by widespread price discounting of } \\
\text { popular brands }\end{array}$} \\
\hline $\begin{array}{l}\text { Per capita programme } \\
\text { spending (in US } \\
1999 \text { dollars) }\end{array}$ & $\begin{array}{l}\text { 1989-93: \$3.27 1993-96: } \\
\$ 1.78^{34}\end{array}$ & $1994-97$ : average $\$ 7.09^{53}$ & $1996-98$ : average $\$ 3.89^{63}$ & 1997-99: $\$ 2.59^{69}$ & 1997: $\$ 2.611998: \$ 4.73^{82}$ \\
\hline $\begin{array}{l}\text { Tobacco industry } \\
\text { intervention }\end{array}$ & $\begin{array}{l}\text { Lobbying to divert } \\
\text { funding from tobacco } \\
\text { control programme } \\
\text { Ratio of industry: } \\
\text { programme spending was } \\
5: 1 \text { in } 1989-93 \text { and } 10: 1 \\
\text { in } 1993-96^{34}\end{array}$ & $\begin{array}{l}\text { Lobbying to divert } \\
\text { funding from } \\
\text { programme } \mathrm{e}^{54}\end{array}$ & $\begin{array}{l}\text { Thought responsible for } \\
1 \text { year delay in } \\
\text { programme spending, so } \\
\text { baseline measures not } \\
\text { gathered, and for limiting } \\
\text { early programme activity } \\
\text { to teens and pregnant } \\
\text { women }^{63}\end{array}$ & $\begin{array}{l}\text { Unsuccessful attempts to } \\
\text { divert funding and limit } \\
\text { the scope and target } \\
\text { groups of the } \\
\text { programme }^{70}\end{array}$ & $\begin{array}{l}\text { Probable behind scenes } \\
\text { lobbying to reduce } \\
\text { programme funding and } \\
\text { fire programme director }\end{array}$ \\
\hline $\begin{array}{l}\text { Programme } \\
\text { components }\end{array}$ & $\begin{array}{l}\text { 1989-96 (average) }{ }^{34} \text { : } \\
\text { Mass media } 17 \% \\
\text { Local lead agency grants } \\
26 \% \\
\text { Competitive grants } 22 \% \\
\text { School based programmes } \\
31 \% \\
\text { Administration and } \\
\text { evaluation } 5 \%\end{array}$ & $\begin{array}{l}1996-97^{53} \text { : } \\
\text { Mass media } 33 \% \\
\text { Local lead agency grants } \\
\text { for cessation, education, } \\
\text { advocacy } 43 \% \\
\text { School programmes } 15 \% \\
\text { Statewide services e.g. } \\
\text { training and quitline } 5 \% \\
\text { Research/evaluation } 4 \%\end{array}$ & $\begin{array}{l}1997-98^{63} \text { : } \\
\text { Mass media and } \\
\text { sponsorships } 54 \% \\
\text { Local lead agency grants } \\
\text { for school education, } \\
\text { cessation, protection from } \\
\text { ETS } 25 \% \\
\text { Info clearinghouse and } \\
\text { quitline } 5 \% \\
\text { Statewide projects, admin } \\
\text { and evaluation } 16 \%\end{array}$ & $\begin{array}{l}1997-99^{69} \text { : } \\
\text { Public awareness and } \\
\text { education } 27 \% \\
\text { Local lead agency grants } \\
38 \% \\
\text { Statewide/regional } \\
\text { projects for quitline, tribal } \\
\text { programmes } 16 \% \text { School } \\
\text { programmes } 12 \% \\
\text { Coordination/evaluation } \\
7 \%\end{array}$ & $\begin{array}{l}1998-99^{82}: \\
\text { Mass media } 37 \% \\
\text { Education/training } 23 \% \\
\text { Youth and community } \\
\text { programmes } 21 \% \\
\text { Enforcement } 12 \% \\
\text { Evaluation } 6 \%\end{array}$ \\
\hline Programme focus & $\begin{array}{l}\text { Adults } \\
\text { Teenagers } \\
\text { Protection of } \\
\text { non-smokers from ETS }\end{array}$ & $\begin{array}{l}\text { Adults } \\
\text { Teenagers } \\
\text { Protection of } \\
\text { non-smokers from ETS }\end{array}$ & $\begin{array}{l}\text { Pre-teenagers } \\
\text { Teenagers } \\
\text { Pregnant women } \\
\text { Adults from mid-1998 }\end{array}$ & $\begin{array}{l}\text { Adults } \\
\text { Teenagers } \\
\text { Protection of } \\
\text { non-smokers from ETS }\end{array}$ & Teenagers \\
\hline
\end{tabular}


Table $2 a$ Overview of evaluation approach and reported outcomes of statewide comprehensive tobacco control programmes to 1999 (part 1)

\begin{tabular}{|c|c|c|c|c|c|}
\hline & California & Massachusetts & Arizona & Oregon & Florida \\
\hline Evaluation elements & $\begin{array}{l}\text { Ongoing cross sectional } \\
\text { population surveys of } \\
\text { adults and teens; Cohort } \\
\text { study of teens; Tracking } \\
\text { of per capita } \\
\text { consumption; Early } \\
\text { fragmented } \\
\text { documentation of uptake } \\
\text { of services; Recent more } \\
\text { detailed evaluation of } \\
\text { programme elements. }\end{array}$ & $\begin{array}{l}\text { Ongoing population } \\
\text { surveys of adults and } \\
\text { teens; Cohort studies of } \\
\text { teens and adults; } \\
\text { Tracking of per capita } \\
\text { consumption; } \\
\text { Documentation of } \\
\text { uptake of services, } \\
\text { programme and policies. }\end{array}$ & $\begin{array}{l}\text { Surveys of recall and } \\
\text { appraisal of campaigns; } \\
\text { Tracking of per capita } \\
\text { consumption; Population } \\
\text { surveys of teens and } \\
\text { adults. }\end{array}$ & $\begin{array}{l}\text { Standardised reports on } \\
\text { programme } \\
\text { implementation, } \\
\text { placement of mass } \\
\text { media, quitline calls; } \\
\text { Surveys of store } \\
\text { advertising/promotions, } \\
\text { clean indoor air and } \\
\text { youth access policies; } \\
\text { Tracking of per capita } \\
\text { consumption; Surveys of } \\
\text { adult and teen smoking. }\end{array}$ & $\begin{array}{l}\text { Information system to } \\
\text { track number and type of } \\
\text { activities undertaken; } \\
\text { Teen and adult surveys } \\
\text { to assess recall of } \\
\text { campaign and beliefs and } \\
\text { attitudes; School surveys } \\
\text { to assess smoking } \\
\text { behaviour; Monitoring of } \\
\text { smoking in teenage } \\
\text { mothers; Surveys of law } \\
\text { enforcement personnel. }\end{array}$ \\
\hline $\begin{array}{l}\text { Mass media campaign } \\
\text { recall and recognition }\end{array}$ & $\begin{array}{l}\text { High levels of campaign } \\
\text { awareness among adults } \\
\text { and teenagers. }{ }^{41445}\end{array}$ & $\begin{array}{l}\text { Increasing majority of } \\
\text { adolescents have seen } \\
\text { and heard campaign } \\
\text { advertising and recognise } \\
\text { campaign theme. }{ }^{57}\end{array}$ & $\begin{array}{l}\text { 1998: } 2 / 3 \text { teens, pregnant } \\
\text { women and adults } \\
\text { reported seeing } \\
\text { advertising in last } 30 \\
\text { days. }^{64}\end{array}$ & $\begin{array}{l}74 \% \text { of adults and } 84 \% \\
\text { of teens recall at least } \\
\text { one campaign } \\
\text { advertisement. }\end{array}$ & $\begin{array}{l}\text { Sept } 1998: 28 \% \text { of teens } \\
\text { reported seeing one } \\
\text { advertisement each day } \\
\text { and } 66 \% \text {, at least one } \\
\text { each week. }{ }^{76} \text { Jan } 1999: \\
48 \% \text { of adults aware of } \\
\text { Truth campaign. }{ }^{77}\end{array}$ \\
\hline $\begin{array}{l}\text { Tobacco industry } \\
\text { advertising and } \\
\text { promotions: awareness } \\
\text { and participation }\end{array}$ & $\begin{array}{l}90 \% \text { teens exposed to } \\
\text { pro-smoking messages. } \\
\text { 1993-96: teen ownership } \\
\text { of promotional items } \\
\text { increased from } 9 \% \text { to } \\
14 \%{ }^{41} 1996: 8 \% \\
\text { newspaper issues } \\
\text { contained pro-tobacco } \\
\text { advertising, } 13 \% \text { public } \\
\text { events sponsored by } \\
\text { tobacco companies. }^{48}\end{array}$ & $\begin{array}{l}\text { 1993-96: high but stable } \\
\text { levels of exposure to } \\
\text { pro-tobacco advertising } \\
\text { on billboards }(80 \%) \text {, } \\
\text { magazines }(74 \%) \text {, and on } \\
\text { clothing }(74 \%) .^{57} 1996 \text { : } \\
31 \% \text { of } 12-17 \text { year olds } \\
\text { owned promotional } \\
\text { item. } .^{57} 1998 \text { : store } \\
\text { advertising highly } \\
\text { prevalent. }\end{array}$ & Not yet reported & Not yet reported & $\begin{array}{l}\text { March 1999: } 56 \% \text { of } \\
\text { stores had tobacco } \\
\text { advertising less than } 3 \\
\text { feet from the ground. } \\
\text { Other data not yet } \\
\text { reported. }\end{array}$ \\
\hline Beliefs and attitudes & $\begin{array}{l}\text { Majority support in } 1996 \\
\text { for a range of tougher } \\
\text { measures to regulate the } \\
\text { industry. }{ }^{41} \text { Very high } \\
\text { levels of agreement by } \\
\text { smokers that smoking } \\
\text { harms their own health } \\
\text { and that ETS causes } \\
\text { disease. }^{41}\end{array}$ & $\begin{array}{l}\text { Teens who recall } \\
\text { campaign advertising } \\
\text { express attitudes } \\
\text { consistent with campaign } \\
\text { intent. } .^{53} \text { Nearly all adults } \\
\text { understand smoking is } \\
\text { unhealthy, see few } \\
\text { benefits to smoking and } \\
\text { view industry with } \\
\text { scepticism. }\end{array}$ & $\begin{array}{l}\text { Change data not yet } \\
\text { reported. }\end{array}$ & $\begin{array}{l}\text { Change data not yet } \\
\text { reported. }\end{array}$ & $\begin{array}{l}\text { Teens more likely to be } \\
\text { unfavourably disposed to } \\
\text { tobacco industry at } \\
\text { follow up. } .^{69}\end{array}$ \\
\hline $\begin{array}{l}\text { Program uptake and } \\
\text { dissemination }\end{array}$ & $\begin{array}{l}\text { 1992-94: } 10,000 \\
\text { multi-session community } \\
\text { programmes provided. }{ }^{42} \\
1995-96: 116 \text { community } \\
\text { programmes funded, } \\
40 \% \text { countering } \\
\text { pro-tobacco, } 19 \% \\
\text { reducing exposure to } \\
\text { ETS, } 19 \% \text { reducing } \\
\text { youth access, } 15 \% \text { on } \\
\text { cessation } / \text { prevention, } 8 \% \text { other. }{ }^{46} 52 \% \text { of } 8 \text { th grade } \\
\text { teachers offered at least } \\
\text { one tobacco prevention } \\
\text { lesson in } 1995-96 .{ }^{46}\end{array}$ & $\begin{array}{l}\text { Over } 3200 \text { local } \\
\text { programme staff trained } \\
\text { to conduct cessation } \\
\text { counselling. }{ }^{53} \text { In fiscal } \\
\text { year } 1997,500,000 \\
\text { education items } \\
\text { distributed. }{ }^{53} \text { Funding } \\
\text { provided to } 282 \text { boards } \\
\text { of health, } 66 \text { primary } \\
\text { health care cessation } \\
\text { programmes, } 45 \text { youth } \\
\text { leadership programmes, } \\
33 \text { special population } \\
\text { programmes, } 19 \text { local } \\
\text { coalitions. }{ }^{53}\end{array}$ & $\begin{array}{l}27 \% \text { of teenagers had } \\
\text { visited the mobile } \\
\text { interactive exhibit called } \\
\text { "the Ashkicker" which } \\
\text { demonstrates dangers of } \\
\text { smoking. }{ }^{64} \text { Other uptake } \\
\text { data not reported. }\end{array}$ & $\begin{array}{l}\text { By } 1998-99 \text {, all counties } \\
\text { had local coalitions, } 24 \\
\text { school prevention } \\
\text { projects were being } \\
\text { implemented, all } 9 \\
\text { Native American tribes } \\
\text { and } 5 \text { organisations } \\
\text { representing ethnic } \\
\text { groups received funds for } \\
\text { prevention and } \\
\text { education, and } 5 \\
\text { demonstration projects } \\
\text { serving pregnant women } \\
\text { and other patient groups } \\
\text { were underway. }{ }^{69}\end{array}$ & 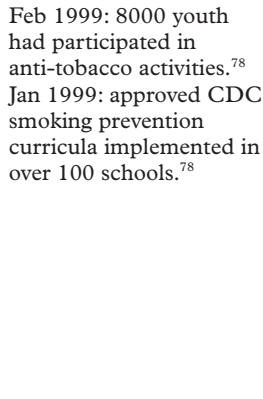 \\
\hline $\begin{array}{l}\text { Environmental and } \\
\text { policy change }\end{array}$ & $\begin{array}{l}\text { Failed retailer } \\
\text { compliance checks fell } \\
\text { from } 52 \% \text { in } 1994 \text { to } \\
22 \% \text { in } 1997,{ }^{47} \text { but no } \\
\text { change in perceived } \\
\text { access by teens. }{ }^{43} 48 \\
\text { Increase in } \% \text { smoke free } \\
\text { workplaces and smoke } \\
\text { free homes. }{ }^{41} \text { No change } \\
\text { in perceived compliance } \\
\text { by teens with school } \\
\text { bans. } .^{4143}\end{array}$ & $\begin{array}{l}\text { 1994-97: Failed retailer } \\
\text { compliance checks fell } \\
\text { from } 48 \% \text { to } 8 \% \text {, but } \\
\text { teens more likely to } \\
\text { obtain from social } \\
\text { sources. }^{5357} 58 \text { 1993-97: } \\
\text { smoking bans more } \\
\text { common in workplaces, } \\
\text { restaurants, homes and } \\
\text { other public places, but } \\
\text { no change in compliance } \\
\text { with school bans. }{ }^{53} 575\end{array}$ & $\begin{array}{l}\text { Change data not yet } \\
\text { reported. }\end{array}$ & $\begin{array}{l}\text { 1995-98: Failed retailer } \\
\text { compliance checks fell } \\
\text { from } 38 \% \text { to } 28 \%{ }^{70} \\
\text { Change data not yet } \\
\text { available for other } \\
\text { policies. }\end{array}$ & $\begin{array}{l}\text { March 1999: } 12000 \\
\text { citations issued for } \\
\text { possession by underage } \\
\text { youth. }{ }^{78}\end{array}$ \\
\hline
\end{tabular}

California legislature has not fully implemented the Proposition 99 funding mandate for tobacco control programmes, and with the exception of the year 1990-91, underfunded tobacco control programme efforts by between $14 \%$ and $51 \%$ of what was promised (and by an average of $32 \%$ between 1989 to 1996$).{ }^{39}$ As table 1 indicates, per capita funding of tobacco control efforts was not only reduced by lower funding in later years of the programme, but was more aggressively counteracted by tobacco industry promotional activities.

The evaluation of the CTCP (table 2a) has involved statewide surveillance of tobacco related attitudes and behaviours of adults and adolescents, ${ }^{40} 41$ tracking of programme implementation, ${ }^{42}$ and more recently an "independent evaluation" linking programme implementation to outcome measures. ${ }^{43}$ However, at the time of writing, only the base- 
Table $2 b$ Overview of evaluation approach and reported outcomes of statewide comprehensive tobacco control programmes to 1999 (part 2)

\begin{tabular}{|c|c|c|c|c|c|}
\hline & California & Massachusetts & Arizona & Oregon & Florida \\
\hline Per capita consumption & $\begin{array}{l}\text { Significant decline } \\
\text { compared with baseline } \\
\text { consumption and by } \\
\text { comparison with rest of } \\
\text { USA and greater than } \\
\text { expected from price } \\
\text { increase alone. }{ }^{40} 4149-51\end{array}$ & $\begin{array}{l}\text { Significant decline } \\
\text { during } 1993-96 \\
\text { compared with baseline } \\
\text { period of } 1990-92 \text { and } \\
\text { for rest of USA, greater } \\
\text { than expected for price } \\
\text { increase alone. }{ }^{60}\end{array}$ & $\begin{array}{l}\text { Decline of } 5.4 \% \text { in } 1995 \\
\text { after adjustment for } \\
\text { stockpiling of lower } \\
\text { priced cigarettes-due to } \\
\text { price increase only, since } \\
\text { programme did not start } \\
\text { until } 1996 .{ }^{66}\end{array}$ & $\begin{array}{l}\text { Significant decline } \\
\text { compared with baseline } \\
\text { consumption and by } \\
\text { comparison with rest of } \\
\text { USA. }^{70}\end{array}$ & Unknown. \\
\hline Adult prevalence & $\begin{array}{l}\text { Rate of decline exceeded } \\
\text { that of rest of USA from } \\
1989 \text { to } 1993 \text {, but was } \\
\text { less than for rest of USA } \\
\text { in } 1993-96 . .^{39}\end{array}$ & $\begin{array}{l}\text { Relative decline of } 9 \% \\
\text { from } 3 \text { years before } \\
\text { programme to first } 3 \\
\text { years of programme, } \\
\text { which was greater than } \\
3 \% \text { decline for rest of } \\
\text { USA. }\end{array}$ & $\begin{array}{l}\text { Change data not yet } \\
\text { reported. }\end{array}$ & $\begin{array}{l}\text { Relative decline of } 6.4 \% \\
\text { to } 21.9 \% \text { in } 1998 \text {, but no } \\
\text { national comparison. }{ }^{69}\end{array}$ & $\begin{array}{l}\text { Change data not yet } \\
\text { reported. }\end{array}$ \\
\hline Teen smoking & $\begin{array}{l}\text { Within state surveys } \\
\text { show no change in } 12-17 \\
\text { year old prevalence from } \\
1990-93 \text { and increase } \\
\text { from } 1993-96 \text {, and } \\
\text { increase in non-smoker } \\
\text { susceptibility }{ }^{41} \text { Among } \\
\text { 8th and } 10 \text { th graders, } \\
\text { relative increase in } \\
\text { smoking prevalence from } \\
1993 \text { to } 1996 \text { was less } \\
\text { than other US states. }^{52}\end{array}$ & $\begin{array}{l}\text { Relative increase in } 30 \\
\text { day prevalence less than } \\
\text { for rest of US for } 8 \text { th and } \\
10 \text { th graders from } 1993 \\
\text { to } 1996^{57} \text { Relative } \\
\text { increase for } 9 \text { th to } 12 \text { th } \\
\text { graders less than for rest } \\
\text { of US from 1993-97 } \\
\text { Relative decline in } \\
\text { lifetime use for } 8 \text { th } \\
\text { graders compared to } \\
\text { increase for rest of } \\
\text { USA. } .^{57}\end{array}$ & $\begin{array}{l}\text { Change data not yet } \\
\text { reported. }\end{array}$ & $\begin{array}{l}\text { Among } 8 \text { th and } 11 \text { th } \\
\text { graders, same as national } \\
\text { trends for first two years } \\
\text { of campaign. }{ }^{69}\end{array}$ & $\begin{array}{l}\text { From February } 1998 \text { to } \\
1999 \text {, relative declines in } \\
30 \text { day prevalence for } \\
\text { middle and high school } \\
\text { students }^{79} \text { were greater } \\
\text { than national trends. }{ }^{79}{ }^{81}\end{array}$ \\
\hline
\end{tabular}

line survey from the independent evaluation was available.

Evaluation of message reach and comprehension has generally shown high levels of media campaign awareness among teenagers, despite few advertising messages having been targeted specifically to them. ${ }^{41}{ }^{44}$ Details of the dissemination of other programme strategies through 1995 are sketchy, but the baseline surveys undertaken for the independent evaluation for 1995/96 provide a much richer source of information on programme activities (table 2a)..$^{43}$ Overall, the programme appears to have documented increased awareness over time in the harm of smoking and passive smoking, stronger support for policy measures, positive change in the extent to which workplaces and homes are smoke free, and reduced access to cigarettes by minors from retail outlets, although there are no comparative analyses that have assessed the rate of change in other states. Cigarette advertising and promotions have been highly prevalent over this period.

Table $2 b$ shows that several econometric studies have demonstrated that the CTCP was associated with a significant decline in per capita cigarette consumption in California, compared with baseline trends in California and trends for the rest of the USA. ${ }^{4041491}$ These studies also provide good evidence that investment in the tobacco control programme exerts independent effects from those of price alone, upon cigarette consumption in California. The introduction of the CTCP was associated with a greater relative decline in adult smoking prevalence in California compared with other states, although this did not persist during 1993-96. ${ }^{39}$ From cross sectional surveys conducted within California, standardised 30 day smoking prevalence did not change among 12 to 17 year olds from 1990 to 1993 (9.2\%), but from 1993 to 1996 it increased significantly from $9.2 \%$ to $12.0 \%$, coincident with the reduced amount of tobacco control funding and the increased ratio of tobacco industry to tobacco control funding. ${ }^{41}$ In addition, there was an increase in the percentage of 12 to 14 year olds who were susceptible to becoming smokers (from $34.5 \%$ in 1993 to $42.0 \%$ in 1996). ${ }^{41}$ Comparison of data from the school based Monitoring the Future surveys shows that although smoking increased in California between 1993 and 1996 in both eighth (relative increase of 16\%) and 10 th graders (relative increase of $6 \%$ ), this was less than was observed for eighth (increase of $29 \%$ ) and 10th graders (increase of $23 \%$ ) in the rest of the USA. ${ }^{52}$

In summary, in the early period of the programme, when programme expenditure was highest and the ratio of tobacco control expenditure to tobacco industry expenditure was most favourable, there was good evidence that progress was made in reducing overall population cigarette consumption and prevalence beyond what would have been expected from a price increase alone. During this period, teenage smoking prevalence stabilised at a time when it increased in the rest of the nation. Since 1994, however, some evidence indicates that effects on both teenage and adult smoking prevalence appear to have been diminished, but trends have remained more positive than for the rest of the nation.

At the beginning of 1999, a voter approved tax increase of 50 cents came into effect. It included a provision to refund the CTCP at earlier levels to make up for the reduction in revenues that otherwise would have occurred as sales fell in response to the new tax increase. These developments in the programme will be of considerable interest and ongoing surveillance and evaluation will document whether it will be associated with more positive future change in teen smoking. 
MASSACHUSETTS (1993-PRESENT)

As the result of a ballot referendum known as

"Question 1", Massachusetts increased the excise tax on tobacco products to take effect in 1993, and established the Massachusetts Tobacco Control Program (MTCP) in October 1993. Of all states, the MTCP had the highest level of per capita funding (table 1), despite the fact that for the programme's first three full fiscal years, the MTCP budget experienced a pattern of decreasing expenditure. ${ }^{53}$ Although the tobacco industry has been active in Massachusetts, attempting to divert funding away from the programme, their response has been less aggressive than was observed in California. $^{54}$

To assess the effectiveness of the MTCP (table 2a), an independent evaluation was commissioned..$^{55}$ The MTCP uses a management information system to document uptake of products and services and change in local policies. Population based surveillance of adult tobacco related knowledge, attitudes, and behaviours was undertaken, ${ }^{56}$ as were surveys of public high school and secondary school students. $^{57}$ In addition, the Youth Risk Behaviour Survey (YRBS) was administered in schools every two years from 1993 to $1997 .^{58}$

Tracking and evaluation studies (table 2a) suggest that the population, including adolescents, experienced high levels of exposure to the MTCP media campaign messages and that there have been positive changes in smoking related beliefs, attitudes, and public support for funding of tobacco control programmes. ${ }^{55-57}$ Within Massachusetts, over the programme period, there has been substantial progress at the local policy level to reduce retailer cigarette sales to minors, increase restrictions on smoking in public places, restrict placement of vending machines, and require permits for tobacco retailers, and at the state level to require disclosure of cigarette nicotine levels and additives. ${ }^{55} 5758$ Like California, however, perceived compliance with bans on smoking in school premises has not changed. ${ }^{57}{ }^{58}$ Access to tobacco from retail outlets appears more difficult, but most teenagers reported that cigarettes were still easy to obtain. Tobacco advertising and promotional efforts continued to be prevalent in Massachusetts following the commencement of the MTCP..$^{59}$

When Massachusetts "Question 1" became effective on 1 January 1993, the real price of cigarettes increased sharply but was eroded from April 1993 by a significant industry initiated price cut that soon offset the tax increase.$^{60}$ Despite this, the resulting short term real price increase combined with the ongoing tobacco control programme activities was associated with a decline in per capita cigarette consumption in Massachusetts for the period 1993 to 1996, greater than that observed for the remainder of the US (excluding California), and for the pre-programme period 1990-92 in Massachusetts. ${ }^{5360}$ The extent of these changes was greater than that expected for a short term price increase alone. Surveys of teenagers in 1993 and 1996, follow- ing the October 1996 tobacco tax increase, indicate that teenagers responded to the price increase by trying to quit, smoking fewer cigarettes and switching to cheaper brands. ${ }^{57} 61$

Table $2 \mathrm{~b}$ indicates that the relative decline in adult smoking prevalence has been greater in Massachusetts than for other states (excluding California). ${ }^{60}$ Indices of teenage smoking in Massachusetts are changing in a positive way. While Massachusetts adolescents had a higher smoking prevalence than those in the rest of the USA before the start of the MTCP, in the three year period following programme commencement, the gap between Massachusetts and the rest of the USA narrowed. ${ }^{57}$ Recently released data from the YRBS also indicate that Massachusetts has had a smaller relative increase in smoking prevalence for ninth through 12th graders combined (ages 14-18 years), than the total US. ${ }^{62}$ For the youngest students, exposure to anti-smoking messages is likely to have begun at a younger age, so that prevention of experimentation with smoking would be most likely to be detected in this subgroup of students. Indeed, comparisons with national data from the MTF surveys show a relative decline of $4.6 \%$ in lifetime cigarette use for eighth graders in Massachusetts (from $52.2 \%$ to $49.8 \%$ ), against a national relative increase of $9.5 \%$ (from $45.3 \%$ to $49.3 \%) .{ }^{57}$ Overall, the evidence for the MTCP being associated with achieving progress in influencing youth tobacco use is positive and consistent.

ARIZONA (1994-PRESENT)

In November 1994, Arizona voters passed Proposition 200, which increased the cigarette excise tax and established the Arizona Tobacco Education and Prevention Program (AzTEPP) . In the early programme years, AzTEPP targeted pre-adolescents, adolescents, pregnant and post-partum women and their partners. An overview of programme elements is contained in table 1. There is good evidence that the tobacco industry was active in attempting to undermine the programme in Arizona. ${ }^{63}$

Evaluation of the programme includes efforts to monitor recall and appraisal of the media elements of the campaign ${ }^{64}{ }^{65}$ and the impact of the price increase on consumption (table 2a). ${ }^{66}$ In addition, the Arizona Department of Health Services undertook baseline surveys of adults and teenagers, ${ }^{67} 68$ although results from subsequent population surveys to judge change are not expected until late 1999.

As intended, and in contrast to California and Massachusetts, the bulk of media messages were designed for adolescents, with over $75 \%$ of the television budget allocated to advertisements aimed at adolescents. ${ }^{65}$ Information available to date from Arizona suggests that after a slow start in the development of the programme, the predominantly youth directed media campaign has been well recalled and positively appraised by adolescents. ${ }^{64}$ Effects on aggregate cigarette consumption were observed in line with expectations based on the extent of the 1994 price increase; this was unsurprising, since campaign activity did not 
commence until one year after funding became available. Survey data also found that smokers aged 10-17 years reported buying fewer cigarettes as a result of the price increase in November 1994, and 15\% had switched to a cheaper brand. ${ }^{67}$ Markers of progress with respect to youth attitudes, exposure to smoking restrictions, reduced youth access, and smoking behaviour will need to await completion of follow up surveys. In addition, the adult focused campaign, which started in 1998, remains to be evaluated and a population survey of adults will provide important information about its impact.

OREGON (1996-PRESENT)

In Oregon, Ballot Measure 44 was passed in November 1996, increasing the tax on cigarettes and resulting in the establishment of the Oregon Tobacco Prevention and Education Program (OTPEP) (table 1). ${ }^{69} \mathrm{~A}$ distinguishing feature of the OTPEP was the decision to use mass media campaign advertising developed by other states that pre-tested well with Oregonians. Evaluation strategies are summarized in table $2 \mathrm{a}$, but since the programme has been in the field for only two full years, relatively limited data are available to assess progress. However, early reports suggest that recall of media messages are high for adults and teenagers, and that a significant amount of progress has been made in implementing community education programmes. ${ }^{69}$ There has been a modest decline in failed retailer compliance checks, ${ }^{71}$ but to date there are no published measures of change in tobacco related knowledge or attitudes, restrictions on smoking in public places, or tobacco industry promotional activity, although these data are being collected.

The extent of decline in per capita consumption following the introduction of the $\mathrm{OTPEP}^{70}{ }^{72}$ is highly consistent with what has been observed in California and Massachusetts (table 2b). Similarly, the observed reduction in adult smoking prevalence mirrors that found in Massachusetts and the early programme period in California, ${ }^{69}$ although final judgement will need to await release of comparable national data. Trends in tobacco use by adolescents in Oregon mirrored national trends for the first two years following commencement of the programme. ${ }^{69}$

FLORIDA (1997-PRESENT)

Unlike the other statewide comprehensive programmes, the Florida Tobacco Pilot Program (FTPP) did not begin its programme with a tax increase, since funding was provided through the provisions of the settlement between the state and tobacco companies (table 1). A strategic plan was released in June $1998^{73}$ which explained that the programme was particularly aimed at reducing tobacco use among teenagers aged $12-17$ years, and a major component has been an aggressive youth oriented media campaign. The so-called "Truth" campaign began in April 1998, and placed particular emphasis on engendering unfavourable attitudes towards the tobacco industry. The programme also fostered community partnerships with all 67 Florida counties, school based initiatives, an education and training initiative, enhanced enforcement of youth tobacco access laws, and a law that penalised youth for possession of tobacco.

The evaluation elements of the programme are summarised in table $2 \mathrm{a}$. To evaluate the media campaign, a media tracking survey was conducted, with successive cohorts of adolescents sampled by telephone, recruited in April (before the campaign), June, and September 1998, and followed up in 1999, ${ }^{74-76}$ and an adult survey was conducted in $1999 .{ }^{77}$ Within the first six weeks after the campaign launch, change was evident in youth attitudes about the behaviour of the tobacco industry, in a direction consistent with a positive impact of the campaign, ${ }^{75}$ and this persisted in a follow up survey in September. ${ }^{76}$ Over the course of the programme, substantial progress has been reported in implementing school based smoking prevention curricula and in involving youth in extracurricula peer education activities. ${ }^{78}$ There was also a heavy emphasis on enforcement of the youth tobacco possession law (table $2 a) .^{78}$

In surveys undertaken by the Florida Department of Health, the prevalence of current cigarette use (use in the past 30 days) among middle school students significantly declined between 1998 and 1999 from 18.5\% to $15.0 \%$ (decline of $18.9 \%$ ) and among high school students from $27.4 \%$ to $25.2 \%$ (decline of $8.0 \%) .{ }^{79}$ Almost all of the decline was among non-Hispanic white students (rather than nonHispanic black or Hispanic students), who had the highest rates of cigarette use at baseline. The trends observed in Florida are larger than any decline observed nationally among youth since $1980,{ }^{80}$ and substantially larger than the modest relative declines observed (of $6.9 \%$ and $1.4 \%$ for middle and high school students, respectively) between 1998 and 1999 from the Monitoring the Future surveys. ${ }^{81}$

Although no tax increase was associated with the start of the campaign, the industry announced a price increase before the start of the campaign and another supposed price increase of 45 cents per pack after the state settlement was announced. Because of promotional discounting practices employed by the tobacco companies, it is unclear to what extent this increase took effect. For example, at the time of writing, Marlboro, Virginia Slims, and some other brands were still discounted by 35 cents per pack. It is not unexpected that, given the nature of the campaign, the tobacco industry might have been active in lobbying to have funding reduced-a mission they may have successfully accomplished in 1999, when the Florida Department of Health announced it would substantially cut back funding to approximately $\$ 2.61$ per capita. ${ }^{82}$

\section{Comparison of state programmes}

Each of the programmes underway in the five states differ by virtue of: their length of time in the field and per capita expenditure on tobacco 
control; the circumstances under which they were initiated; background trends in teenage smoking prevalence against which they will be judged; the relative allocation of funding to general tobacco control strategies as opposed to youth specific approaches; selection of messages and strategies within each programme component; extent of actual compared with intended implementation; and measures used to assess progress. When appraised individually, it is difficult to draw firm conclusions about the effectiveness of particular mixes of programme inputs in reducing teenage tobacco use. However, when taken together, a number of consistent findings emerge.

First, we find that one of the single most critical factors in programme success is the extent of funding, and the degree to which this is undermined by the tobacco industry and other competitors for funding. More fully funded programmes lead to increased expenditure on mass media campaigns and community initiatives; a greater capacity to implement school based smoking prevention programmes; and an increase in the passage of local ordinances that create smoke free indoor environments and reduce youth access. These factors create an environment more favourable for reduced teenage tobacco use. As known from previous research, these changes in the policy environment are very likely to lead to reductions in youth smoking prevalence and consumption. However, it is unclear at this stage whether or not significant reductions in youth access are being achieved. While stronger enforcement may lead to retailers being less likely to sell directly to minors, there is some suggestion that this is at least partially offset by underage smokers using older peers to buy for them and otherwise obtaining their cigarettes from social sources. ${ }^{43} 58$ Similarly, while there has been great improvement in the extent of smoking restrictions in workplaces, restaurants, other public places and private homes, compliance with bans on smoking on school premises is low. ${ }^{41} 57$

Second, there is strong evidence from these comprehensive programmes, coupled with other research, that price increases influence overall and adolescent tobacco use and that the addition of programme activity reduces consumption more than expected because of price alone. Variation in per capita cigarette consumption reflects changes in the numbers of cigarettes smoked by smokers and the number of people who smoke. Monthly sales data based on tax receipts from wholesale cigarette deliveries are relatively sensitive instruments for detecting change at the population level.

One of the potential limitations of taxable sales data for cigarettes is that estimates of per capita consumption are based on tax receipts at the wholesale level, rather than the number of packs consumed. Distributors may delay or advance shipments in anticipation of announced wholesale price changes or tax increases, thereby producing year to year changes in tax receipts that do not reflect changes in consumption. Aggregation of data over several years, as has been done in most state evaluations, will help to minimise the influence of these practices, and reflect actual consumption more accurately. A second potential limitation is that the data reflect only packs sold within the state, so that if smokers increasingly travel out of state to obtain cheaper cigarettes, taxable sales data will not reflect this. While this is possible, and the tobacco industry have often used this argument to provide an alternative explanation for reductions in per capita cigarette consumption, it is very unlikely to be the case in practice. As demonstrated in various analyses, bordering states have similar or even higher tax rates (for example, Oregon), have not evidenced increases in consumption (for example, Arizona), are not easily accessible for cigarette purchase for most of the population (for example, California), or would make a negligible difference to per capita consumption, even if all increases in sales in a neighbouring state with lower tax were explained by cross-border purchases (for example, Massachusetts). Taken together, there is strong evidence from these comprehensive programmes, coupled with other research, that price increases influence adolescent tobacco use- and that the addition of programme activity reduces consumption more than that expected for price alone.

Third, there is consistent evidence the programmes are associated with a decline in adult smoking prevalence, with these effects observed to date in California, Massachusetts, and Oregon. Arizona and Florida, which are conducting more youth focused campaigns, have yet to examine change in adult prevalence associated with programme exposure. These changes in the normative environment for smoking, along with reduced opportunities to smoke and the message of social undesirability offered by increased bans on smoking, are likely to be an important influence on youth smoking.

Finally, despite the different strengths and combinations of programme messages and strategies used in these comprehensive programmes, the evidence that they change factors that influence teenage smoking, and to reductions in teenage smoking prevalence and uptake, is compelling. Plainly, for programmes like Arizona, which has yet to report follow up data, and Florida, which is early in its development, more research is needed to clarify and confirm important early indications of positive progress.

\section{Conclusions}

Given progress made by programmes in the field and other experimental and research evidence, it is concluded that comprehensive tobacco control programmes are an effective strategy for reducing teenage smoking. As US states decide what level of funding from their tobacco settlement money should be allocated to programmes to reduce teenage tobacco use, decision makers should not use "lack of evidence for benefit" as an argument to avoid making such allocations. Maine, Maryland, 
Mississippi, and Minnesota have recently started comprehensive tobacco control programmes. By mid-1999, a number of states that settled with the tobacco companies in the November 1998 multi-state settlement agreement, including Vermont, Hawaii, and Washington, had committed substantial funding for comprehensive programmes. Some other states have committed smaller amounts of funding, but most other states have yet to decide. Tobacco control advocates in other countries should take similar heed from the results of, and lessons learned by, the five US state comprehensive tobacco control programmes and pursue avenues for funding and implementation. Recently, the US Department of Health and Human Services issued guidelines for best practice for funding and implementation of comprehensive tobacco control programmes, ${ }^{83}$ thereby providing an additional important resource for decision makers. In addition, the Institute of Medicine have also just issued a report as a resource for tobacco control advocates and funding decision makers, summarising evidence that state comprehensive tobacco control programmes can reduce tobacco use. ${ }^{84}$

The most difficult aspect of conducting this review was that, in many cases, equivalent data from states without comprehensive tobacco control programmes were unavailable. Similarly, the data from states with comprehensive tobacco control programmes were often not directly comparable. Surveillance efforts undertaken by the National Cancer Institute as part of its ASSIST evaluation, ${ }^{5}$ by the Center for Disease Control and Prevention's Office on Smoking and Health, ${ }^{85}$ and a few others ${ }^{86}$ are beginning to provide the comparable data from all states that are necessary for more systematic evaluations of state efforts. Continued collection of these data and their analysis will further enhance our understanding of the optimal mix of tobacco control strategies in reducing teenage smoking.

The research and writing of this report was supported by grants from the Campaign for Tobacco-Free Kids and the Rober Wood Johnson Foundation. The views expressed herein are those of the authors and do not necessarily reflect the views of We thank the programme and evaluation the funding agencies. We thank the programme and evaluation staff in each of the states with comprehensive tobacco contro programmes who provided information, clarification, and and plans. A longer version of this paper is available at and plans. A longer version of this
www.uic.edu/orgs/impacteen/pub fs.htm

Disclaimer: Melanie Wakefield serves as a senior editor for Tobacco Control. Michael Siegel acted as guest editor for this manuscript. Dr Wakefield was excluded from reviewer correspondence and excused herself from participation in editorial meetings where the manuscript was discussed.

1 National Cancer Institute. Strategies to control tobacco use in the United States: a blueprint for public health action in the 1990's. Bethesda, Maryland: National Institutes of Health, 1991. (Publication No (NCI) 92-3316).

2 Shopland DR. Smoking control in the 1990's: a National Cancer Institute model for change. Am f Public Health 1993;83:1208-10

3 Manley M, Lynn W, Epps RP, et al. The American stop smoking intervention study for cancer prevention: an overview. Tobacco Control 1997;6(suppl 2):S5-11.

4 McKinlay JB. More appropriate evaluation methods for community-level health interventions. Eval Review 1996; 20:237-43.

5 Stillman F, Hartman A, Graubard B, et al. The American stop smoking intervention study: conceptual framework and evaluation design. Eval Review 1999;23:259-80.

6 Tobler NS. Drug prevention programs can work: research findings. Fournal of Drug Issues 1992;11:1-28.
7 Bruvold WH. A meta-analysis of adolescent smoking prevention programs. Am f Public Health 1993;83:872-80. 8 US Department of Health and Human Services. Preventing tobacco use among young people. A report of the Surgeon General, 1994. Atlanta, Georgia: Public Health Service, Centers for Disease Control and Prevention, Office on Smoking and Health, 1994. (US Government Printing Office Publication No S/N 017-001-00491-0.

9 Botvin GJ, Renick NL, Baker AK, et al. The effects of scheduling format and booster sessions on a broadspectrum psychosocial smoking prevention program. $f$ Behav Med 1983;6:359-79.

10 Perry CL, Klepp K-I, Schultz JM. Primary prevention of cardiovascular disease: community-wide strategies for youth. F Consult Clin Psychol 1988;56:358-64.

11 Flay BR, Koepe D, Thomson SJ, Santi S, Best JA, Brown KS. Six year follow-up of the first Waterloo school smoking prevention trial. Am f Public Health 1989; 79:1371-6.

12 Eckhardt L, Woodruff SI, Elder JP. Related effectiveness of continued, lapsed and delayed smoking prevention intervention in senior high school students. American fournal of Health Promotion 1997;11:418-21.

13 Flynn BS, Worden JK, Secker-Walker RH, et al. Mass media and school interventions for cigarette smoking prevention: effects two years after completion. Am 7 Public Health effects two years

14 Perry CL, Kelder SH, Murray DM, Klepp K-I. Community-wide smoking prevention: long term outcomes of the Minnesota heart health program and the class of 1989 study. Am F Public Health 1992;82:1210-16.

15 Pierce JP, Dwyer T, Frape G, et al. Evaluation of the Sydney "Quit for Life" anti-smoking campaign: part 1. Achievement of intermediate goals. Med f Aust 1986;144:341-4.

16 Pierce JP, Macaskill P, Hill DJ. Long-term effectiveness of mass-media anti-smoking campaigns in Australia. $A m \mathcal{F}$ Public Health 1990;80:565-9.

17 Bauman KE, Brown JD, Bryan ES, et al. Three mass media campaigns to prevent adolescent smoking. Prev Med 1988; $17: 510-30$

18 Bauman KE, Padgett CA, Koch GG. A media-based campaign to encourage personal communication among adolescents about not smoking cigarettes: participation, selection and consequences. Health Educ Res 1989;4:3544.

19 Bauman KE, LaPrelle J, Brown JD, et al. The influence of three mass media campaigns on variables related to adolescent smoking: results of a field experiment. $\mathrm{Am} \mathcal{f}$ Public Health 1991;81:597-604.

20 Forster JL, Murray DM, Wolfson M, et al. The effects of community policies to reduce youth access to tobacco. $\mathrm{Am}$ 7 Public Health 1998;88:1193-8.

21 Rigotti NA, DiFranza JR, Chang YC, et al. The effect of enforcing tobacco sales laws on adolscents' access to tobacco and smoking behavior. N Engl f Med 1997; 337:1044-51

22 Chaloupka FJ, Pacula RL. Limiting youth access to tobacco: the early impact of the Synar Amendment on youth smoking. Department of Economics, University of Illinois at Chicago, 1998.

23 Forster JL, Wolfson M. Youth access to tobacco: policies and politics. Annu Rev Public Health 1998;19:203-35.

24 Pentz MA, Dwyer JH, MacKinnon DP, et al. A multicommunity trial for primary prevention of adolescent drug munity trial for primary preven
abuse. $¥ A M A$ 1989;261:3259-66.

25 Chaloupka FJ, Grossman M. Price, tobacco control policies and youth smoking. National Bureau of Economic Research, Working Paper No. 5740, 1996. http://papers.nber.org/ papers/W5740

26 Tauras JA, Chaloupka FJ. Clean indoor air laws and cigarette smoking: evidence from longitudinal data from young adults. National Bureau of Economic Research, Working Paper No. 6937, 1999. http://papers.nber.org/papers/W6937

27 Chaloupka FJ, Warner KE. The economics of smoking. In: Newhouse JP, Culyer AJ, eds. New York: North Holland. In press.

28 US Department of Health and Human Services. Reducing the health consequences of smoking: 25 years of progress. A report of the Surgeon General, 1989. Rockville, Maryland: Public Health Service, Centers for Disease Control, Office on Smoking and Health, 1989. (DHHS Publication No (CDC) 89-8411.)

29 US Department of Health and Human Services. Tobacco use among U.S. raciallethnic minority groups: African Americans, American Indians and Alaska Natives, Asian Americans and Pacific Islanders, Hispanics. A report of the Surgeon General, 1998. Atlanta, Georgia: Centers for Disease Control and Prevention, Office on Smoking and Health, 1998. (US
Government Printing Office Publication No S/N 017Government Print

30 Goldstein AO, Fisher PM, Richards JW, Creten D. Relationship between high school student smoking and recognition of cigarette advertisements. F Pediatrics 1987;110:488-91.

31 DiFranza JR, Richards JW, Paulman PM, et al. RJR Nabisco's cartoon camel promotes Camel cigarettes to children. fAMA 1991;266:3149-53.

32 Evans N, Farkas A, Gilpin E, et al. Influence of tobacco marketing and exposure to smokers on adolescent suscep-

33 Pierce JP, Choi WS, Gilpin EA, et al. Tobacco industry promotion of cigarettes and adolscent smoking. $\mathcal{F A M A} 1998$; 279:511-15. 
34 Lewit EM, Hyland A, Kerrebrock N, Cummings KM. Price, public policy and smoking in young people. Tobacco

35 Chaloupka FJ, Wechsler H. Price, tobacco control policies and smoking among young adults. f Health Econ

36 Dee TS, Evans WN. A comment on DeCicca, Kenkel and Mathios. Working Paper, School of Economics, Georgia Institute of Technology, 1998

37 Evans WN, Huang LX. Cigarette taxes and teen smoking: new evidence from panels of repeated cross-sections. ( Maryland, 1998.

38 Wakefield M, Chaloupka FJ. Improving the measuremen and use of tobacco control 'inputs'. Tobacco Control 1998; 7:333-5.

39 Pierce JP, Gilpin EA, Emery SL, et al. Has the California tobacco control program reduced smoking? $¥ A M A$ 1998;280:893-9.

40 Pierce JP, Evans N, Farkas AJ, et al. Tobacco use in California: an evaluation of the tobacco control program, 1989-1993. A report to the California Department of Health Services. La Jolla, California: Cancer Prevention and Control Program, University of California, San Diego, 1994.

41 Pierce JP, Gilpin EA, Emery SL, et al. Tobacco control in California: who's winning the war? An evaluation of the tobacco control program, 1989-1996. La Jolla, California: University of California, San Diego, 1998. http:// ssdc.ucsd.edu/tobacco/reports/

42 Elder JP, Edwards CC, Conway TL, et al. Independent evaluation of the California tobacco education program. Public Health Rep 1996;111:353-8.

43 Independent Evaluation Consortium. Final report of the independent evaluation of the California tobacco prevention independent evaluation of the California tobacco prevention and education program: wave 1 data, 1996

44 Popham WJ, Potter LD, Hetrick MA, et al. Effectiveness of the California 1990-1991 tobacco education media campaign. Am f Prev Med 1994;10:319-26.

45 Howard-Pitney B, Schooler C, Spanjian L. Community and media programs and activities: accountability assessment. Independent Evaluation Consortium. Final report of the independent evaluation of the California tobacco prevention and education program: wave 1 data, 1996-1997. Rockville, Maryland: Gallup Organization, 1998

46 Rohrbach L, Dent C, Johnson CA, et al. Evaluation of school tobacco use prevention education programs. Independent Evaluation Consortium. Final report of the independent evaluation of the California tobacco prevention and education program: wave 1 data, 1996-1997. Rockville, Maryland: Gallup Organization, 1998

47 California Department of Health Services. California's tobacco control program: preventing tobacco-related disease and tobacco control program: preventing tobacco-related disease and Control Section, 1998.

48 Boley Cruz T, Johnson CA, Unger J, et al. Tobacco industry monitoring evaluation (TIME). Independent Evaluation Consortium. Final report of the independent evaluation of the California tobacco prevention and education program: wave 1 data, 1996-1997. Rockville, Maryland: Gallup Organization, 1998

49 Glantz SA. Changes in cigarette consumption, prices, and tobacco industry revenues associated with California's proposition 99. Tobacco Control 1993;2:311-4.

$50 \mathrm{Hu}$ T, Sung H, Keeler TE. Reducing cigarette consumption in California: tobacco taxes vs. and anti-smoking media campaign. Am f Public Health 1995;85:1218-22.

$51 \mathrm{Hu}$ T, Sung H, Keeler TE. The state anti-smoking campaign and the industry response: the effects of campaign and the industry response: the effects of Econ Assoc Papers and Proceedings 1995;85:85-90.

52 Unger J, Johnson CA, Rohrbach L, et al. Integration of tobacco control efforts. Independent Evaluation Consortium. Final report of the independent evaluation of the California tobacco prevention and education program: wave 1 data, 1996-1997. Rockville, Maryland: Gallup Organization, 1998.

53 Begay ME, Glantz SA. Question 1 tobacco education expenditures

54 Siegel M, Biener L. Evaluating the impact of statewide antitobacco campaigns: the Massachusetts and California Tobacco Control Programs. I Social Issues 1997;53:14768.

55 Abt Associates Inc. Independent evaluation of the Massachusetts tobacco control program. Fourth annual report, January 1994 to June 1997. Prepared for the Massachusetts Department of Public Health.

56 Biener L, Roman AM. 1995 Massachusetts adult tobacco survey (technical report). Boston, Massachusetts: Center for Survey Research, University of Massachusetts, Boston, 1997

57 Briton NJ, Clark TW, Baker AK, et al. Adolescent tobacco use in Massachusetts: trends among public schoo students, 1984-1996. Boston, Massachusetts: Health and Addictions Research Inc. 1997. www.state.ma.us/dph/ $\mathrm{mtcp} / \mathrm{report} / \mathrm{handa}$.htm

58 Massachusetts Department of Education. Tobacco use among Massachusetts high school students: 1997 Massachusetts Youth Risk Behavior Survey results, 1998. www.state.ma.us/dph/mtcp/youth.htm

59 Massachusetts Department of Public Health. Massachusetts Operation Storefront 1998. www.state.ma.us/dp $\mathrm{h} / \mathrm{mtcp} /$ report/osrep.htm
60 Harris JE, Connolly GN, Brooks D, Davis B. Cigarette smoking before and after an excise tax increase and an anti-smoking campaign-Massachusetts, 1990-1996. MMWR Morbid Mortal Wkly Rep 1996;45:966-70.

61 Biener L, Aseltine RH, Cohen B, Anderka M. Reactions of adult and teenaged smokers to the Massachusetts tobacco tax. Am F Public Health 1998;88:1389-91.

62 Division of Adolescent and School Health and Office on Smoking and Health, National Center for Disease Control and Prevention, CDC. Cigarette smoking among high school students-11 States, 1991-1997. MMWR Morbid Mortal Wkly Rep 1999;48:686-92.

63 Bialous SA, Glantz SA. Arizona's tobacco control initiative illustrates the need for continuing oversight by tobacco control advocates. Tobacco Control 1999;8:141-51.

64 Eisenberg $\mathrm{M}$, Lee $\mathrm{H}$, Burgoon $\mathrm{M}$, et al. Historical impact of the TEPP media campaign: report no. 1. University of Arizona, Arizona Cancer Center, 1998.

65 Eisenberg M, Hogan T. Historical cost-effectiveness of the media campaign. Arizona State University, Arizona Cancer Center and L William Seidman Research Institute, 1999.

66 Hogan TD. The impact of proposition 200 on cigarette consumption in Arizona. Report from Arizona State University for American Cancer Society, Arizona Division, August 1996.

67 Arizona Department of Health Services. 1997 Arizona youth tobacco survey baseline report, Epidemiologic report series 1998:2. Phoenix, Arizona: Arizona Department of Health Services, 1998. www.tepp.org/evaluation/1997youthbaseline/index.html

68 Arizona Department of Health Services. 1996 Arizona adult tobacco survey report, Epidemiologic report series 1997:2. Phoenix, Arizona:Arizona Department of Health Services, 1997. www.tepp.org/evaluation/1996adultsurvey/

69 Oregon Health Division. Tobacco prevention and education program report 1999. Portland, Oregon: Department of Human Resources, 1999.

70 Pizacani B, Mosbeck C, Hedberg K, et al. Decline in cigarette consumption following implementation of a comprehensive tobacco prevention and education
program-Oregon, 1996-1998. MMWR Morbid Mortal Wkly Rep 1999;48:140-3.

71 Goldman LK, Glantz SA. The passage and initial implementation of Oregon's measure 44. Tobacco Control $1999 ; 8: 311-22$

72 Oregon Health Division. Oregon tobacco facts, April 1999. Tobacco Prevention and Education Program, Portland, Oregon. www.ohd.hr.state.or.us/cdpe/hpcdp/tobacco/ facts $99 /$ home.htm

73 Florida Department of Health, 1998. www.state.fl.us/ tobacco/

74 Sly DF, Heald G, Hopkins, et al. The industry manipulation attitudes of smokers and nonsmokers. Center for the Study of Population, Florida State University, 1999.

75 Center for the Study of Population. Florida anti-tobacco media evaluation, fuly 1998. Florida State University, 1998.

76 Center for the Study of Population. Florida anti-tobacco media evaluation, September 1998. Florida State University, 1998.

77 Florida Department of Health. BRFSS adult tracking survey, volume 1, report 1. August 1999. www.state.fl.us/tobacco/

78 Kershaw JM. Monthly evaluation report, issue 99-01. Florida Department of Health, March 1, 1999. www.state.fl.us/ tobacco/

79 Bauer U, Johnson T, Pallentino J, Hopkins R, et al. Tobacco use among middle and high school students-Florida, 1998 and 1999. MMWR Morbid Mortal Wkly Rep 1999;48:248-53.

80 University of Michigan News and Information Services. Smoking among American teens declines some. Ann Arbor, Michigan: University of Michigan, Press Release, December 18, 1998 .

81 University of Michigan News and Information Services. Cigarette smoking among American teens continues gradual decline. Ann Arbor, Michigan: University of Michigan, Press Release, December 17, 1999.

82 Givel MS, Glantz SA. Tobacco industry political power and influence in Florida from 1979 to 1999. San Francisco: Institute for Health Policy Studies, School of Medicine, University of California, California, May 1999. www.library.ucsf.edu/tobacco/fl/

83 Centers for Disease Control and Prevention. Best practices for comprehensive tobacco control programs-August 1999. for comprehensive tobacco control programs-August 1999. Services, Centers for Disease Control and Prevention, National Center for Chronic Disease Prevention and Health Promotion, Office on Smoking and Health, August 1999. www.cdc.gov/to bacco/bestprac.htm

84 Institute of Medicine and National Research Council. State programs can reduce tobacco use. National Cancer Policy Board, Institute of Medicine, National Research Council and Board on Health Promotion and Disease Prevention, Institute of Medicine. Washington: National Academy of Sciences, February 2000. http://books.nap.edu/html/ state_tobacco

85 Office on Smoking and Health. State tobacco activities tracking and evaluation system. Centers for Disease Control and Prevention, US Department of Health and Human Services. http://www2.cdc.gov/nccdphp/osh/state/

86 University of Illinois at Chicago. ImpacTeen: a policy research partnership to reduce youth substance abuse. Chicago: UIC. www.uic.edu/orgs/impacteen 